\title{
Dogs for the Gods, Fish for the Feast: The Ceremonial Role of Animals at Kaminaljuyu, Guatemala
}

\author{
Ashley E. Sharpe (D, Bárbara Arroyo, Javier Estrada, Gloria Ajú, and Emanuel Serech
}

\begin{abstract}
This study examines the ritual and socioeconomic significance of animals in ceremonial contexts at Kaminaljuyu, Guatemala. Kaminaljuyu was once the largest and most politically powerful highland Maya center. We compare faunal remains from different contexts, including burials and dedicatory offerings in and around monumental features, to better understand the role of animals in these deposits. We then compare ceremonial activities across Mesoamerica to identify similarities alluding to widely recognized practices. Late and Terminal Preclassic (350 BC-AD 250) ceremonies at Kaminaljuyu contain some of the earliest marine fish recovered from a Maya highland site, demonstrating the ability of early elites to obtain exotic species for special events. Dogs, including perhaps the first evidence for Preclassic hairless dogs in Guatemala, appear in deposits that resemble canine sacrificial offerings in central Mexico. The new faunal data in this study provide a novel perspective on Kaminaljuyu's sociopolitical role in the region.
\end{abstract}

Keywords: Maya, Kaminaljuyu, ritual fauna, domestic dogs, fish

Este estudio examina el significado ritual y socioeconómico de los animales en contextos ceremoniales del sitio Kaminaljuyu, Guatemala. Kaminaljuyu fue uno de los centros más grandes y políticamente poderosos del Altiplano Maya. Este trabajo compara los restos de fauna de distintos contextos ceremoniales, incluyendo entierros y ofrendas dedicatorias adentro y alrededor de rasgos monumentales, para comprender el papel de los animales en estos depósitos. Estas actividades ceremoniales se comparan a otras áreas mesoamericanas para identificar similitudes que aluden prácticas ampliamente reconocidas. Las ceremonias del Preclásico Tardío y Terminal (350 aC-250 dC) en Kaminaljuyu utilizaron pescados marinos, los más antiguos recuperados de un sitio del Altiplano Maya, posiblemente demostrando la habilidad que tuvieron las elites para obtener especies exóticas para sus rituales desde tiempos ancestrales. Los perros, incluyendo la primera evidencia de perros sin pelo en Guatemala, aparecen en depósitos que tienen similitudes a ofrendas de cánidos sacrificados en el centro de México. Los nuevos datos de la fauna de esta investigación proporcionan una perspectiva novedosa para apreciar el papel sociopolítico de Kaminaljuyu en la región.

Palabras clave: Maya, Kaminaljuyu, fauna ritual, perros domésticos, peces

$\mathrm{A}$ nimals have long been recognized as an important part of Mesoamerican ceremonies. Sometimes they were used as offerings, such as the canines, eagles, and marine species enclosed in stone containers within Tenochtitlan's Templo Mayor (López Luján et al. 2014) or the menagerie of carnivores in
Teotihuacan's pyramids (Sugiyama et al. 2015). Sacrificial animals were chosen for particular occasions, such as to commemorate important events, sanctify a structure or location, ask a favor of or thank the gods, and honor or accompany a human individual into the afterlife (deFrance 2009). Animals were also important

Ashley E. Sharpe (SharpeAE@si.edu, corresponding author) — Center for Tropical Paleoecology and Archaeology, Smithsonian Tropical Research Institute, Balboa-Ancón, Republic of Panama

Bárbara Arroyo, Javier Estrada, Gloria Ajú, and Emanuel Serech a Proyecto Zona Arqueológica Kaminaljuyu, Zona 7, Guatemala City, Guatemala

Latin American Antiquity 33(2), 2022, pp. 221-241

Copyright (C) The Author(s), 2021. Published by Cambridge University Press on behalf of the Society for American Archaeology. This is an Open Access article, distributed under the terms of the Creative Commons Attribution-NonCommercialShareAlike licence (http://creativecommons.org/licenses/by-nc-sa/4.0/), which permits non-commercial re-use, distribution, and reproduction in any medium, provided the same Creative Commons licence is included and the original work is properly cited. The written permission of Cambridge University Press must be obtained for commercial re-use. 


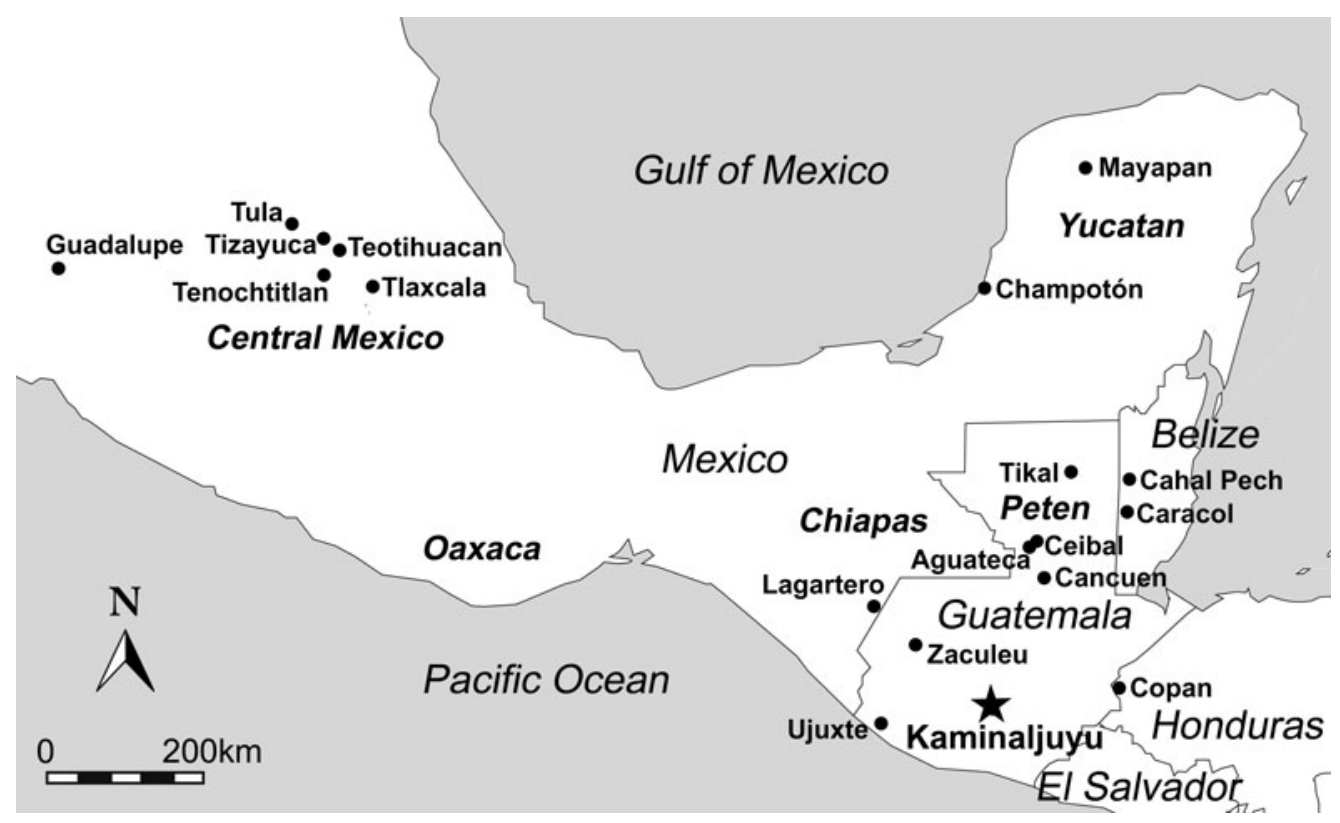

Figure 1. Map of Mesoamerica showing sites mentioned in the article.

for feasts (Rosenswig 2007). In addition, faunal materials served as ornamentation and musical instruments, such as turtle shell drums and long bone rasps, or as plumage and fur for costumes. The remains of these items are found in the archaeological record, but their original functions can be ambiguous when they are found in midden or fill contexts, separated from the activity in which they had been involved.

In this study, we analyze several animal assemblages recently recovered from the site of Kaminaljuyu, Guatemala (Figure 1), to interpret the roles of animals in ancient highland ceremonies. These assemblages primarily date to the Late Preclassic through Early Classic periods (350 BC-AD 550), when Kaminaljuyu reached its political apogee. We compare these contexts with other animal assemblages from special deposits throughout the Mesoamerican region to understand how Guatemala's highland ceremonies reflect broader ritual practices.

Kaminaljuyu was one of the major highland centers that participated in the Maya obsidian trade network (Love 2011). The presence of monumental architecture across the site indicates that the early ruling class promoted ceremonial activities to engage the public, display elite prowess, and commune with supernatural forces.
Kaminaljuyu's leaders maintained economic and political relations with other sites such as Tikal in northern Guatemala and Copan in western Honduras (Arroyo et al. 2020; Braswell 2003). There is even architectural and artifactual evidence to suggest that Kaminaljuyu had political ties with Teotihuacan in central Mexico during the late Early Classic period (AD 400-550). Examining the ceremonial uses of animals at Kaminaljuyu provides further evidence of the inhabitants' relationships with these distant political centers.

Our study addresses the following questions. Can we interpret the nature and purpose of the different deposits containing animals at Kaminaljuyu? Did Kaminaljuyu's inhabitants engage in ceremonial activities resembling those at other centers? Did early rulers procure rare or nonlocal animals for ceremonies, thereby demonstrating their ability to obtain these resources? What was the role of dogs in Kaminaljuyu's ceremonies, and do Kaminaljuyu's rituals help us understand the symbolic roles that dogs played in Mesoamerica?

\section{Environment and History of Kaminaljuyu}

Kaminaljuyu is located $1,500 \mathrm{~m}$ asl near three active volcanoes. The highland climate is cool 
and dry compared to the rest of the country. The settlement was concentrated between several steep ravines in the Valley of Guatemala. Today, it is a roughly $2 \mathrm{~km}^{2}$ segment of Guatemala City, but its original footprint may have been larger.

Excavations at Kaminaljuyu have revealed a dynamic and long-lasting community, beginning at least as far back as the Middle Preclassic period $(800 \mathrm{BC})$. The settlement surrounded the now nonexistent Lake Miraflores. By the Late Preclassic period (350-100 BC), inhabitants were mining local obsidian sources to make fine blades and other cutting implements. The presence of this same obsidian at lowland Preclassic communities hundreds of kilometers away indicates that an obsidian trade network had been established by this time (Aoyama 2017; Love 2011). Kaminaljuyu's early elites likely used this trade network to their advantage and cemented political control through alliances in the region.

Archaeological excavations and paleoecological cores indicate that Lake Miraflores began to recede around AD 100-200 (Popenoe de Hatch et al. 2002). Remains of irrigation channels confirm that complex hydraulic projects focused on channeling water were an important enterprise among the Preclassic inhabitants (Arroyo and Henderson 2020). The lake was a low-level marsh when the Spanish arrived. Diminution of the lake would have reduced the local inhabitants' ability to access freshwater resources. Comparisons of artwork through time at the site show that aquatic symbolism, common in the Preclassic, had decreased considerably by the later Classic period (Henderson 2013:281; Serech 2017).

Kaminaljuyu's role as an important highland political center continued during the Early Classic period (AD 250-550). There is ceramic and architectural evidence for Teotihuacan influence in Kaminaljuyu's monumental projects and ceremonial activities by the latter part of this period (Arroyo et al. 2020). The political relationship between these two distant centers, however, remains unclear. By the Late Classic period (AD 550-800), Kaminaljuyu's economic connections and population began to decline. Increased agricultural and political instability during the Terminal Classic period (AD 800900), in part driven by a series of severe droughts and the diminishing lake, caused Kaminaljuyu's eventual political collapse.

Today, the best-preserved area of the site is beneath the Kaminaljuyu Archaeological Park, which includes the Acropolis and Palangana complexes (Figure 2). Kaminaljuyu once had more than 200 mapped mounds. Only a few dozen remain, and those that are not in the park are under threat. In the 1940s, archaeologists working with the Carnegie Institution of Washington, DC, were asked by the Guatemalan authorities to examine mounds facing imminent destruction. The first mounds they excavated were Mounds A and B, which contained several large Early Classic tombs with numerous marine and terrestrial animal offerings (Kidder et al. 1946:145-157). The archaeologists returned a few years later to excavate Mound E-III-3, the largest structure at the site, before it was destroyed for a development project. Mound E-III-3 contained two tombs with the remains of Kaminaljuyu's earliest rulers, both dating to the Terminal Preclassic period (100 BC-AD 250; Shook and Kidder 1952). These excavations produced the first detailed reports of highland Maya burials and associated animal offerings.

A series of excavations by different organizations were carried out over the twentieth and twenty-first centuries, all of which improved our understanding of the ancient highland settlement as it was swallowed up by the modern metropolis. Most did not report faunal data. An exception was the Parque Kaminaljuyu Archaeological Project (Ivic de Monterroso and Alvarado Galindo 2004). Fauna from these excavations were analyzed by Kitty Emery and colleagues (2013) and included mainly construction fill deposits within the archaeological park.

Since 2010, excavations have been conducted by the Proyecto Zona Arqueológica Kaminaljuyu (ZAK; Kaminaljuyu Archaeological Zone Project). Although the aim of this research is to examine and preserve the structures within the Kaminaljuyu Archaeological Park, the project has also prioritized rescue projects throughout the modern city. Our study focuses on four parts of the site from these excavations: (1) a 


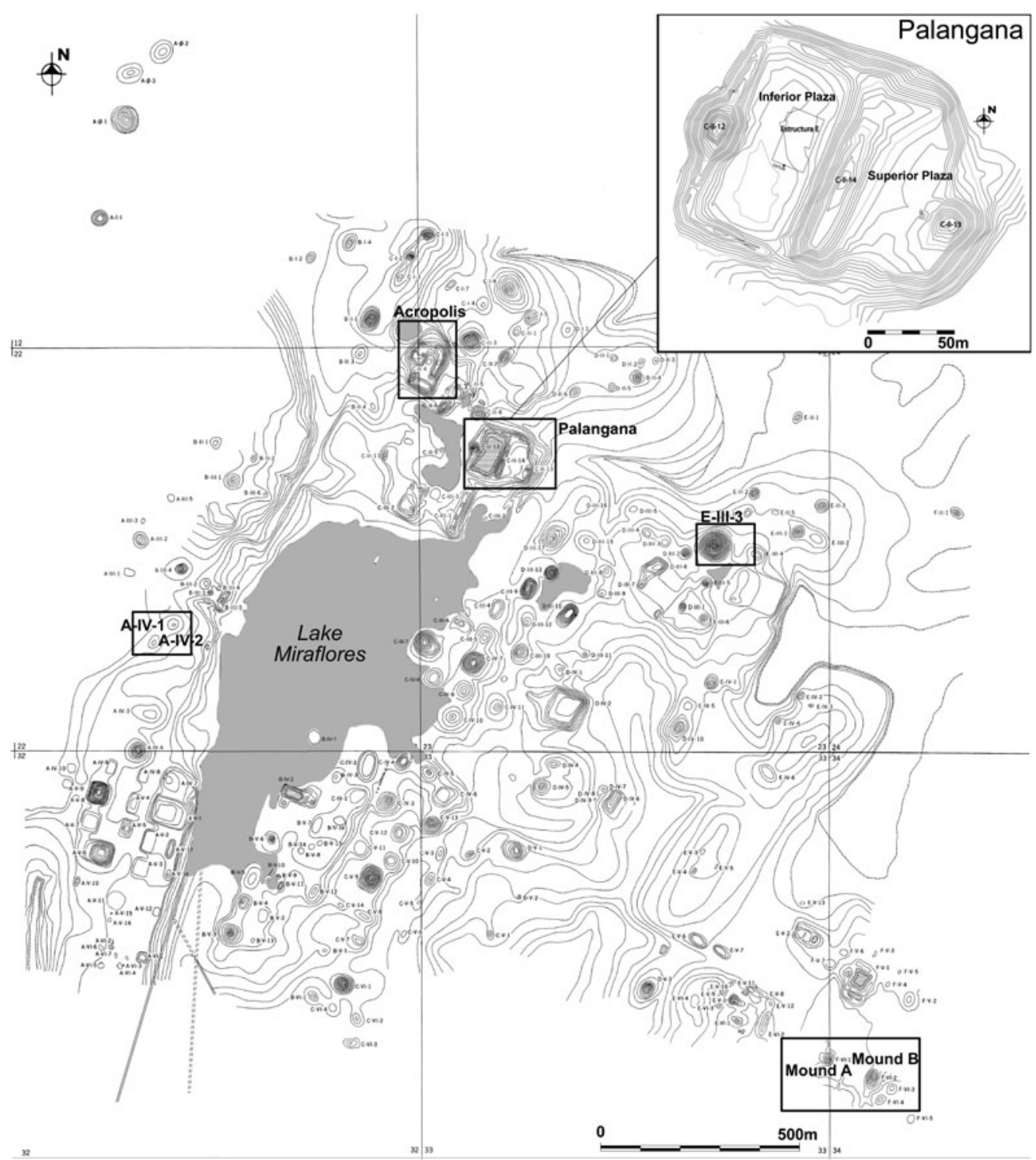

Figure 2. Map of Kaminaljuyu and the contexts reviewed in this article.

large deposit at the base of what had been Mound E-III-3, (2) a dense deposit of animals and other materials in the Palangana, (3) the Acropolis, and (4) the area around Mounds A-IV-1 and A-IV-2.

The large deposit at the base of what had been Mound E-III-3 was discovered in 2015, when ZAK conducted an exploratory operation in the parking lot that now covers this mound's location. It recovered the remains of disturbed burials from a salvage project in the 1970s (Estrada de la Cerda 2017:30), which were surrounded by hundreds of shattered Late Preclassic ceramic vessels, worked and unworked stone objects, and carbonized seeds and organic material. The archaeologists at first thought the burials were earlier versions of the elite tombs found in the original structure, but the large quantity of shattered vessels and other artifacts indicates it may be a dedicatory offering preceding the construction of Mound E-III-3.

The Palangana is an unusual feature that had been remodeled over the course of a thousand 


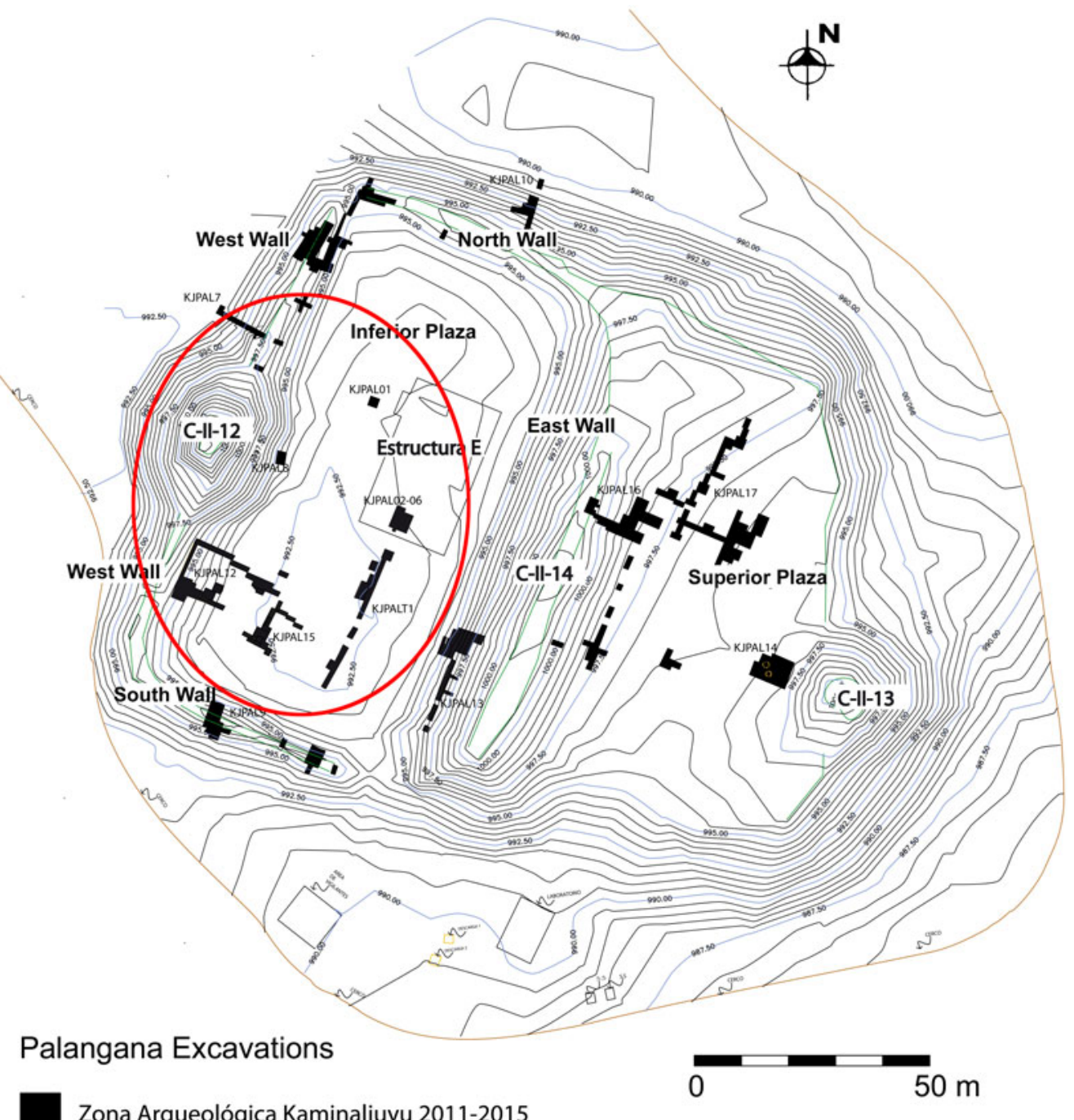

Zona Arqueológica Kaminaljuyu 2011-2015

Figure 3. Map of the Palangana excavations, with estimated area of the Gran Depósito outlined in red. (Color online)

years. Lying near the original northern shore of Lake Miraflores, it was designed as a ceremonial space between three long, parallel platforms running north-south that may have held performances during the Preclassic period (Ajú Álvarez 2017). During the Classic period, the eastern half was elevated (the Superior Plaza), whereas the western half remained low (the Inferior Plaza). ZAK excavations covered both Superior and Inferior parts of the plaza, as well as surrounding structures (Figure 3). Excavations in the Superior Plaza did not reveal any faunal material. However, a Terminal Preclassic artifact deposit more than $50 \mathrm{~m}^{2}$ in the Inferior Plaza contained hundreds of animal remains. This was designated the Gran Depósito de Materiales by the excavators (hereafter, the Gran Depósito). The Gran Depósito contained four human burials, although whether they were conventional interments or were offerings themselves is still under investigation.

The Acropolis is a series of ceremonial structures $250 \mathrm{~m}$ west of the Palangana, primarily dating to the Classic period (AD 250-900). Several structures were designed in the talud-tablero style of central Mexico and the city of Teotihuacan. Because the Acropolis served both a ceremonial and governing function at Kaminaljuyu, 
arrivals from Teotihuacan may have included elite personages involved with political affairs. The fauna identified from the Acropolis construction fill likely represents discard from Classic period elites who lived in this area.

Mounds A-IV-1 and A-IV-2 were located near the western shore of Lake Miraflores. Salvage excavations in this area discovered a series of Terminal Preclassic and Early Classic burials and cache-like artifact concentrations of ceramic, bone, and other items (Serech 2018). The dense artifact deposits could be discard from ceremonial events, intentional cache offerings, or perhaps both. The human burials in this area contained animal remains; because these individuals were not royal elites, the grave items provide information about lesser or non-elite funerary practices.

\section{Materials and Methods}

ZAK recovered the faunal remains in this study from 2010 to 2016 using a quarter-inch mesh. Bones were analyzed using the comparative skeleton collection at the Smithsonian Tropical Research Institute in Panama City, Panama. Identifications of specimens were made to the lowest taxonomic rank possible. Animal ages were documented when bone fusion or tooth development could be ascertained. Cut marks were described and categorized as either deep cuts (gouges $>2 \mathrm{~mm}$ wide or deep) or lighter, thin cuts (Supplemental Table 1). We considered purposefully smoothed cuts around the outside circumference of a bone or occasionally lengthwise to be the products of artifact manufacture. Finished or near-finished artifacts included incised decorations, beads, and awls.

Specimens were quantified using the number of identified specimens (NISP; Reitz and Wing 2008:202). This count was made conservatively because most specimens were fragmented. If fragmented bones could be refit, they were counted as NISP $=1$. However, in cases where crania and long bones were shattered in a single deposit, nondiagnostic fragments were each counted as NISP $=1$. When possible, we quantified the minimum number of individuals (MNI; Reitz and Wing 2008:205-206). MNI is an estimate of the lowest number of individual animals from a particular species, based in part on the number of repeating elements of the same side in a single context (e.g., four right dog femurs are $\mathrm{MNI}=4$ ) and the ages (i.e., juveniles and adults) of the animals present. Only unmixed, chronologically distinct contexts were used to determine MNI.

\section{Results}

Table 1 lists a summary of the fauna identified (see Supplemental Table 2 for an expanded list including MNI). Mammals are the most common class in three contexts (>95\%), with the exception of fish (Actinopterygii) in the Mound E-III-3 deposit (69.0\%). Domestic dogs (Canis lupus familiaris) were the most common mammal in all contexts. The Mound E-III-3 deposit had the largest diversity of species (27 vertebrates, 1 invertebrate). Dogs, white-tailed deer (Odocoileus virginianus), and rabbits (Sylvilagus floridanus) were found in all four locations; armadillos (Dasypus novemcinctus) and gophers (Orthogeomys hispidus) were found in three of the four locations. Many species were found at both the E-III-3 deposit and the Gran Depósito, such as bobwhite quails (Colinus sp.), greattailed grackles (Quiscalus mexicanus), mud turtles (Kinosternidae), catfish (Siluriformes), cichlids (Cichlidae), snook (Centropomus sp.), and grunts (Pomadasys sp.). A few species were represented by one or a few bones belonging to a single individual, including bones of a turkey (Meleagris sp.) in the Acropolis, a tapir (Tapirella bairdii) and possible bull shark (Carcharhinus leucas) in the Gran Depósito, and a mullet (Mugil sp.) in the Mound E-III-3 deposit.

\section{Comparison of Ceremonial Fauna by Context}

The Mound E-III-3 deposit had the greatest variety of taxa recovered from any single location. The assemblage differs considerably from the two elite tombs found by Carnegie Institution in the E-III-3 structure. Table 2 compares these assemblages using species categories, because the Carnegie reports did not consistently quantify remains. These two elite tombs contained only six species: armadillo, large feline, porcupine fish, unidentified fish, stingray, and 
Table 1. Summary of Specimen Identifications.

\begin{tabular}{|c|c|c|c|c|c|c|c|c|c|}
\hline \multirow[b]{2}{*}{ Species Name } & \multirow[b]{2}{*}{ Common Name } & \multicolumn{2}{|c|}{$\begin{array}{c}\text { E-III-3 Base } \\
\text { (Late Preclassic) }\end{array}$} & \multicolumn{2}{|c|}{$\begin{array}{c}\text { Gran Depósito } \\
\text { (Terminal Preclassic) }\end{array}$} & \multicolumn{2}{|c|}{$\begin{array}{c}\text { A-IV-1/A-IV-2 Area } \\
\text { (Late Preclassic- Early } \\
\text { Classic) }\end{array}$} & \multicolumn{2}{|c|}{$\begin{array}{c}\text { Acropolis } \\
\text { (Mixed Classic) }\end{array}$} \\
\hline & & NISP & $\%$ & NISP & $\%$ & NISP & $\%$ & NISP & $\%$ \\
\hline Mammalia & Unidentified mammal & 233 & 48.1 & 438 & 39.9 & 65 & 20.4 & 21 & 31.8 \\
\hline Didelphis virginiana & Virginia opossum & 2 & 0.4 & - & - & 85 & 26.6 & - & - \\
\hline Dasypus novemcinctus & Armadillo & 9 & 1.9 & 14 & 1.3 & 1 & 0.3 & - & - \\
\hline Sylvilagus cf. floridanus & Cottontail rabbit & 5 & 1.0 & 2 & 0.2 & 14 & 4.4 & 3 & 4.5 \\
\hline Rodentia & Rodent & 27 & 5.6 & - & - & - & - & - & - \\
\hline Orthogeomys hispidus & Pocket gopher & 17 & 3.5 & 11 & 1.0 & - & - & 2 & 3.0 \\
\hline Carnivora & Unidentified carnivore & 2 & 0.4 & - & - & 14 & - & - & - \\
\hline Canis lupus familiaris & Domestic dog & 95 & 19.6 & 605 & 55.2 & 128 & 40.1 & 26 & 39.4 \\
\hline Felidae & Jaguar/puma & 1 & 0.2 & - & - & - & - & - & - \\
\hline Tapirella bairdii & Tapir & - & - & 1 & 0.1 & - & - & - & - \\
\hline Tayassuidae & Peccary & 1 & 0.2 & - & - & - & - & 1 & 1.5 \\
\hline Cervidae & Deer & 2 & 0.4 & - & - & 3 & 0.9 & 1 & 1.5 \\
\hline Odocoileus virginianus & White-tailed deer & 9 & 1.9 & 6 & 0.5 & 7 & 2.2 & 10 & 15.2 \\
\hline Aves & Unidentified bird & 16 & - & 3 & 0.3 & - & - & - & - \\
\hline Colinus sp. & Bobwhite quail & 3 & 0.6 & 1 & 0.1 & - & - & - & - \\
\hline Ortalis sp. & Chachalaca & 1 & 0.2 & - & - & - & - & - & - \\
\hline Meleagris sp. & Turkey & - & - & - & - & - & - & 2 & 3.0 \\
\hline cf. Fulica americana & American coot & 1 & 0.2 & - & - & - & - & - & - \\
\hline Columbina inca & Inca dove & 4 & 0.8 & - & - & - & - & - & - \\
\hline Icteridae & Grackles/orioles & 4 & 0.8 & - & - & - & - & - & - \\
\hline Quiscalus mexicanus & Great-tailed grackle & 1 & 0.2 & 15 & 1.4 & - & - & - & - \\
\hline Testudines & Turtle & 17 & 3.5 & - & - & - & - & - & - \\
\hline Trachemys venusta & Mesoamerican slider & 7 & 1.4 & - & - & - & - & - & - \\
\hline Kinosternidae & Mud/musk turtle & 24 & 5.0 & 1 & 0.1 & - & - & - & - \\
\hline Serpentes & Snake & 2 & 0.4 & - & - & - & - & - & - \\
\hline Anura & Frog/toad & 1 & 0.2 & - & - & - & - & - & - \\
\hline Rhinella marina & Cane toad & - & - & - & - & 2 & 0.6 & - & - \\
\hline Total Non-Fish & & 484 & $30.9 \%$ total & 1,097 & $98.1 \%$ total & 319 & $100.0 \%$ total & 66 & $98.5 \%$ total \\
\hline Actinopterygii & Unidentified fish & 757 & 70.0 & 11 & 52.4 & - & - & - & - \\
\hline Siluriformes & Catfish & 12 & 1.1 & 2 & 9.5 & - & - & - & - \\
\hline Rhamdia sp. & Catfish & 2 & 0.2 & - & - & - & - & - & $\overline{(\text { Continued })}$ \\
\hline
\end{tabular}


Table 1. Continued.

\begin{tabular}{|c|c|c|c|c|c|c|c|c|c|}
\hline \multirow[b]{2}{*}{ Species Name } & \multirow[b]{2}{*}{ Common Name } & \multicolumn{2}{|c|}{$\begin{array}{c}\text { E-III-3 Base } \\
\text { (Late Preclassic) }\end{array}$} & \multicolumn{2}{|c|}{$\begin{array}{c}\text { Gran Depósito } \\
\text { (Terminal Preclassic) }\end{array}$} & \multicolumn{2}{|c|}{$\begin{array}{c}\text { A-IV-1/A-IV-2 Area } \\
\text { (Late Preclassic- Early } \\
\text { Classic) }\end{array}$} & \multicolumn{2}{|c|}{$\begin{array}{c}\text { Acropolis } \\
\text { (Mixed Classic) }\end{array}$} \\
\hline & & NISP & $\%$ & NISP & $\%$ & NISP & $\%$ & NISP & $\%$ \\
\hline Cichlidae & Cichlid & 163 & 15.1 & 2 & 9.5 & - & - & - & - \\
\hline Mugil sp. & Mullet & 2 & 0.2 & - & - & - & - & - & - \\
\hline Centropomus sp. & Snook & 26 & 2.4 & 4 & 19.0 & - & - & - & - \\
\hline Lutjanus sp. & Snapper & 6 & 0.6 & - & - & - & - & - & - \\
\hline Pomadasys sp. & Grunt & 6 & 0.6 & 1 & 4.8 & - & - & - & - \\
\hline Dormitator latifrons & Pacific fat sleeper & 108 & 10.0 & - & - & - & - & - & - \\
\hline cf. Carcharhinus leucas & Bull shark & - & - & 1 & 4.8 & - & - & - & - \\
\hline Total Fish & & 1,082 & $69.0 \%$ total & 21 & $1.9 \%$ total & 0 & 0 & 0 & 0 \\
\hline Mollusca (marine?) & Unidentified mollusk & 1 & 50.0 & - & - & - & - & - & - \\
\hline cf. Anadara tuberculosa & Ark clam & 1 & 50.0 & - & - & - & - & - & - \\
\hline Gastropoda, large marine & Marine snail & - & - & - & - & - & - & 1 & 100.0 \\
\hline Total Mollusks & & 2 & $0.1 \%$ total & $\mathbf{0}$ & $\mathbf{0}$ & $\mathbf{0}$ & $\mathbf{0}$ & 1 & $1.5 \%$ total \\
\hline Grand Total & & 1,568 & & 1,118 & & 319 & & 67 & \\
\hline
\end{tabular}

Note: Proportions calculated according to total number of fish, nonfish vertebrates, or mollusks in each category, unless otherwise indicated. 
Table 2. Number of Distinct Species in Ceremonial Contexts.

\begin{tabular}{|c|c|c|c|c|c|}
\hline Category & $\begin{array}{l}\text { E-III-3 Base } \\
\text { (Late } \\
\text { Preclassic) }\end{array}$ & $\begin{array}{c}\text { E-III-3 Tombs } 1 \& 2 \\
\text { (Terminal } \\
\text { Preclassic) }\end{array}$ & $\begin{array}{l}\text { Gran Depósito } \\
\text { (Terminal } \\
\text { Preclassic) }\end{array}$ & $\begin{array}{c}\text { Mound A } \\
\text { Tombs } \\
\text { (Early Classic) }\end{array}$ & $\begin{array}{c}\text { Mound B } \\
\text { Tombs } \\
\text { (Early Classic) }\end{array}$ \\
\hline Mammals & 10 & 2 & 6 & 7 & 5 \\
\hline Birds & 5 & - & 2 & - & 3 \\
\hline Reptiles & 3 & - & 1 & 2 & - \\
\hline Amphibians & 1 & - & - & - & - \\
\hline Freshwater fish & 2 & - & 1 & - & - \\
\hline Marine fish & 2 & 2 & 1 & 1 & 1 \\
\hline Unknown/mixed habitat fish & 4 & 1 & 3 & - & - \\
\hline Freshwater mollusks & - & - & - & 1 & 1 \\
\hline Marine mollusks & 1 & 1 & - & 11 & 11 \\
\hline Total & 28 & 6 & 14 & 22 & 21 \\
\hline
\end{tabular}

Spondylus oyster. Only the armadillo and feline bones compare with specimens found in the Late Preclassic base deposit. The Early Classic royal tombs recovered in Mounds A and B have more faunal diversity but still less than that observed in the Mound E-III-3 base deposit. Marine mollusks made up half the animal species found in the royal tombs. The only marine shell in the Mound E-III-3 base deposit was a Pacific ark clam (Anadara tuberculosa), not found in the later tombs. Mound E-III-3's base deposit also had a larger variety of vertebrate taxa, including several freshwater and marine species. Yet it shared species in common with the Early Classic tombs, including dogs, large felines, peccaries (Tayassuidae), deer, bobwhite quail, and slider turtles (Trachemys venusta; carapaces only, possibly used as drums). In sum, the Mound E-III-3 base deposit is more similar to the Early Classic royal tombs in terms of animal species than the two Preclassic tombs that had been found within its own structure. However, it also contained many more terrestrial, marine, and aquatic vertebrates than any single deposit, tomb or otherwise, at Kaminaljuyu.

Comparing these tombs with the Palangana's Gran Depósito, we found little affinity between species composition in the deposits (Table 1). Domestic dogs made up $55.2 \%$ of the terrestrial vertebrates, representing at least 14 individuals. Fish were only $1.9 \%$ of the total NISP and included genera found in the Mound E-III-3 base deposit such as cichlids, catfish, and snook. Unique species included a bull shark tooth and a partial tapir mandible, the first representatives of both found at Kaminaljuyu.

The Mound A-IV-1/A-IV-2 area had six deposits containing human remains. These, along with nine other concentrated artifact deposits lacking human remains but located in the same area, are summarized in Table 1 (see Supplemental Table 3 for contextual details). Although the burial offerings lack the diversity of the royal tombs, the animals appear to be intentional interments and not from associated fill. A near-complete opossum (Didelphis virginianus), partial rabbit, and cane toad (Rhinella marina) were placed around the burial of a possible adolescent female dating to the Early Classic. The burial also contained a ceramic pitcher with the face of a snouted, toothy animal that may be an opossum (Figure 4). Two other burials in the Mound A-IV-1/A-IV-2 area had the only deer antlers identified in this study. Four of the nine nonburial deposits in this area, possibly middens of quotidian origin, contained dogs.

The Acropolis fill had many of the same taxa found in the previous deposits, including rabbits, gophers, dogs, and deer. Dogs made up 39.4\% of Acropolis vertebrates. The analysis by Emery and colleagues (2013) of the Classic period fill around the Acropolis and elsewhere in the Kaminaljuyu Archaeological Park found no evidence of dogs. However, unmixed Classic period contexts in that study only contributed to $8.3 \%$ of the total NISP (Emery et al. 2013:394-395), so the lack of Classic dogs may have been due to the small sample. 


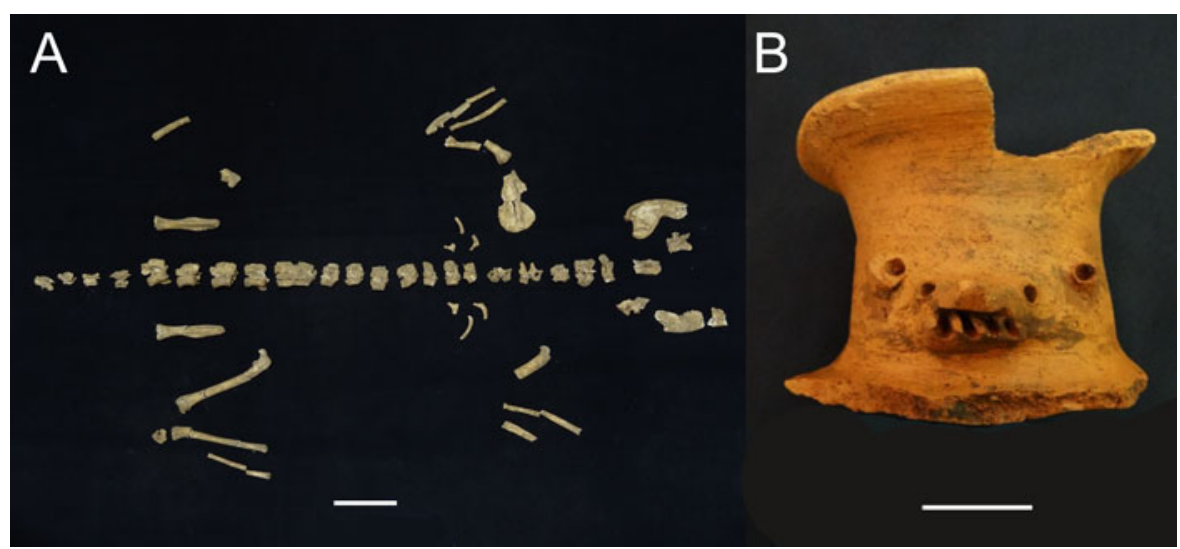

Figure 4. Opossum skeleton and vase effigy found with a burial near Mound A-IV-1. Scale bars 5 cm (photographs by Emanuel Serech). (Color online)

ZAK excavations recovered two turkey bones in the plaza northeast of the Acropolis, possibly from the same bird. This is the first evidence for turkeys at Kaminaljuyu, indicating they were brought to the highlands during the Classic period. Because the bones were fragmented, we could not determine whether it was an ocellated (Meleagris ocellata) or wild/northern turkey (Meleagris gallopavo). Both species are not native to the highlands (Thornton and Emery 2017) and may have been part of the dietary or ceremonial activities of the Acropolis elites.

\section{Comparison of Burning and Human Modifications}

Examining patterns among specimens exhibiting signs of burning, cut marks, or other modifications can help determine the use of these animal products and the nature of the deposits where they were recovered. No Acropolis bones were burned, and few specimens were burned in the Mound A-IV-1/A-IV-2 deposits (Figure 5). In contrast, almost $94 \%$ of the Mound E-III-3 deposit's remains were burned. Burning included light browning to completely bluewhite calcined fragments, sometimes on the same bone and indicative of uneven heating. The conflagration occurred after the bones were deposited with the other offerings. The gopher bones exhibited partial burning, suggesting these large rodents were not intrusive but were part of the original deposit (smaller rodents like pocket mice, however, were unburned and possibly intrusive). A considerable amount of ash was noted throughout the deposit during the excavation, indicating that a fire had been kept alive for hours by burning various organic materials (Estrada de la Cerda 2017:38-39).

Evidence for burning was found on $19.3 \%$ of the bones in the Gran Depósito. Unlike the Mound E-III-3 deposit, burned items and ash were found dispersed in various areas. The Gran Depósito was likely several different deposition events confined to the Palangana's Inferior Plaza; the deposition activity may have taken place over the course of days, weeks, or a few years. Radiocarbon samples and ceramic from the deposit layers date to the Terminal Preclassic period (100 BC-AD 250; Ajú Álvarez 2017:26; Arroyo and Ajú 2021). Because the Gran Depósito is located $3 \mathrm{~m}$ underground and covers most of the Inferior Plaza, it was excavated in a series of trenches. Thus, we do not have a complete idea of the spatial layout of the deposit, although ongoing research on the nonfaunal artifacts and future excavations may be able to enhance our understanding of the deposition sequence.

Comparing the types of human-made surface modifications provides another means to distinguish the nature of different deposits (Figure 5; Supplemental Table 1). The Acropolis had the highest proportion of cut bones (10.4\%), including two dogs and four deer. It also had the highest proportion of worked artifacts (3.0\%). The Gran Depósito had the highest gross number of cut and scrape marks on bones, including eight dogs 


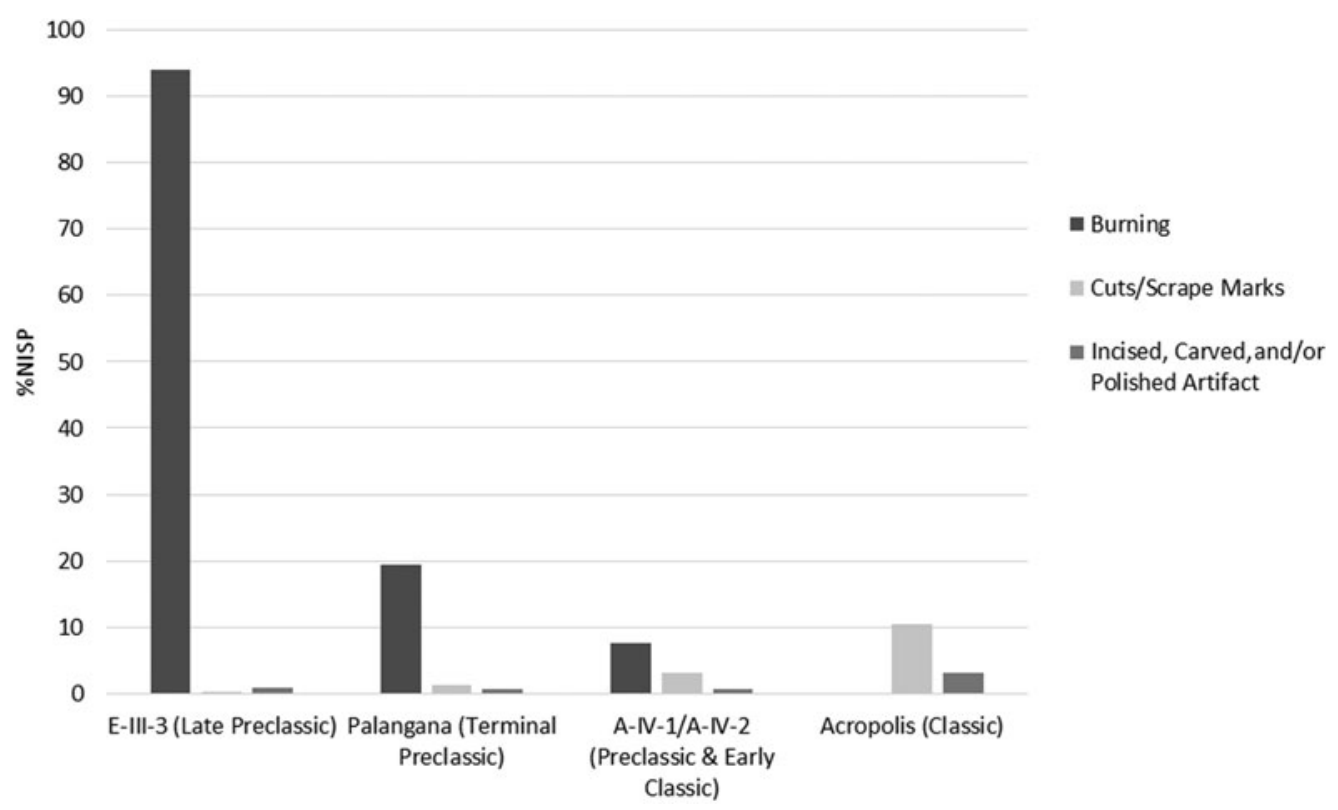

Figure 5. Proportion of specimens exhibiting burning, cut marks, and other modifications, based on total NISP in each deposit.

and three deer. It contained a few finished artifacts, including the drilled shark tooth (Figure 6C). The burials and concentrated artifact deposits around Mounds A-IV-1/A-IV-2 had nearly a dozen cut bones. Seven were dogs, two were rabbits, and there was one deer. In most cases, cuts were made on different elements near joints. They may indicate skinning or, for deeper cuts, removal of flesh in the butchery process.

The Mound E-III-3 base deposit had the largest number (11) of finished artifacts, which included bone pins, a partial bead, and a broken awl. One deer humerus, lightly burned, had been cut longwise down the center and was painted red (Figure 6A). Another unique artifact was a possible rattle formed from a mud turtle shell (Figure 6B). The carapace was found near a cluster of more than 400 obsidian pebbles, which may have been inside the shell originally (Estrada de la Cerda 2017:108). Two similar rattles were found by Kidder and colleagues (1946:156) in the royal Classic tombs; they also contained hundreds of obsidian pebbles.

Altogether, these data suggest that the Mound E-III-3 base deposit contained finished artifactual items purposefully placed and burned as a single event. The number of finished artifacts indicate it may be a tomb, although since these objects were broken and scattered, it is more likely they belong to a ceremony preceding the construction of Mound E-III-3. By contrast, the Gran Depósito was an accumulated series of events in the same area, containing the remains of processed food items, as well as finished and broken ornamental artifacts. The Mound A-IV-1/A-IV-2 deposits contained a mix of animal offerings placed near human burials. Nonburial deposits in that area contained remains of skinned or butchered animals. Animals from the Acropolis fill likely represent the remains of food preparation and consumption by Classic period elites.

\section{Analysis of Domestic Dogs}

Domestic dogs were found in all four study areas (Table 1). There were at least three disarticulated dogs in the Mound E-III-3 base deposit, at least one of which had been burned. This individual had five unfused limb bones and was likely a younger subadult, about 6-12 months in age (Supplemental Table 4; von Pfeil and DeCamp 2009). Light cuts were identified on a proximal femoral head and the distal medial malleolus of a tibia. These dogs may have been consumed during a feast associated with the deposit, placed 


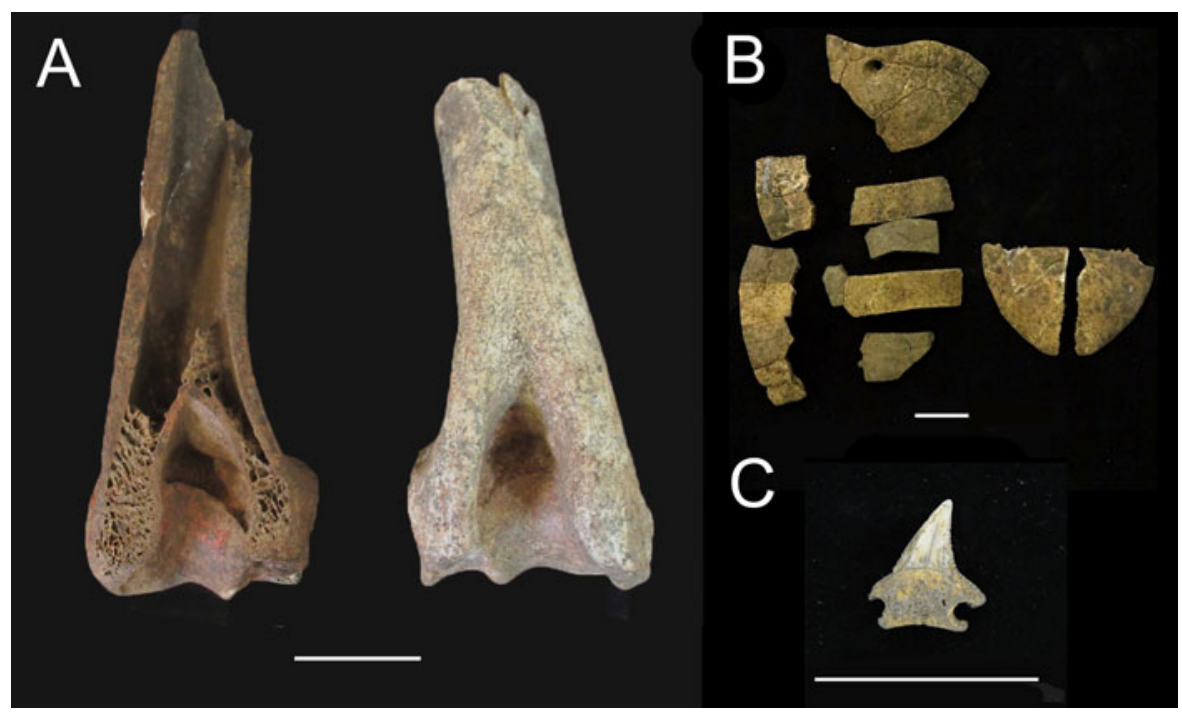

Figure 6. Artifacts from the Mound E-III-3 deposit and Gran Depósito: (A) white-tailed deer right and left humeri from Mound E-III-3; (B) mud turtle shell found in the Mound E-III-3 deposit alongside obsidian flakes, possibly a rattle; (C) possible bull shark tooth from the Gran Depósito. Scale bars $2 \mathrm{~cm}$ (photographs by Ashley Sharpe). (Color online)

as offerings, or were the remains of both these activities combined.

The majority of identified specimens in the Palangana's Gran Depósito were dogs, representing at least 14 individuals. Most skeletal elements were represented, indicating that the dogs were primary deposits, but they were disarticulated and scattered. Dogs were the majority of burned specimens in the Gran Depósito (57.6\%). In one instance, the articulated paws of a dog were documented in situ near several obsidian blades and the remains of a human child, possibly representing an offering (Ajú Álvarez 2014:56). All other dogs were disarticulated, although right and left elements of some individuals could be found centimeters apart.

The Gran Depósito dogs were a mix of adult, subadult, and juvenile individuals, although due to their intermixed state it was impossible to associate elements to reconstruct their ages. A total of 39 bones were found in an intermediary state of fusion, but at a large enough size to indicate the animals were subadults. Seven bones were small and unfused, and had the characteristic "spongey" appearance of puppies only a few months old. There was no clear pattern as to where the puppies were found in the deposit. Five bones were cut: two vertebrae along the ventral side (Figure 7), two right femurs with light cuts just below the proximal head, and a left tibia deeply cut $(>1 \mathrm{~mm})$ on the dorsal side of the shaft. If the Palangana's Gran Depósito was a series of related ceremonial events, these dogs may have been the remains of feasts or offerings.

Dogs made up the majority of the deposits in the Mound A-IV-1/A-IV-2 area (40.1\% of vertebrates). One disarticulated skeleton with cut marks (lot KJAIV1(n)-H4/5-1) was less than a year old based on fusion. One of its cervical vertebrae had two light parallel cuts along the central ventral ridge and one deeper cut on the left lateral ventral ridge (Figure 7C). Other light cuts were identified on the distal end of a rib, the ventral side of a left radius, across the surface of the right radial carpal, along the distal epiphysis of a right tibia, on the proximal surface of the left cuneiform, and horizontally across the condyle of the right talus (Figure 8). These light cuts focusing on joints and the neck area were likely from butchery or skinning, comparable with similar evidence of dog consumption elsewhere in the world (e.g., Murphy 2001).

There were 26 bones representing at least eight dogs in the Acropolis. Two bones were cut: a left humerus with two light cuts on the central shaft and a mandible with a deep ( $>2 \mathrm{~mm}$ wide) cut. This suggests that dogs were also consumed during the later Classic period. 


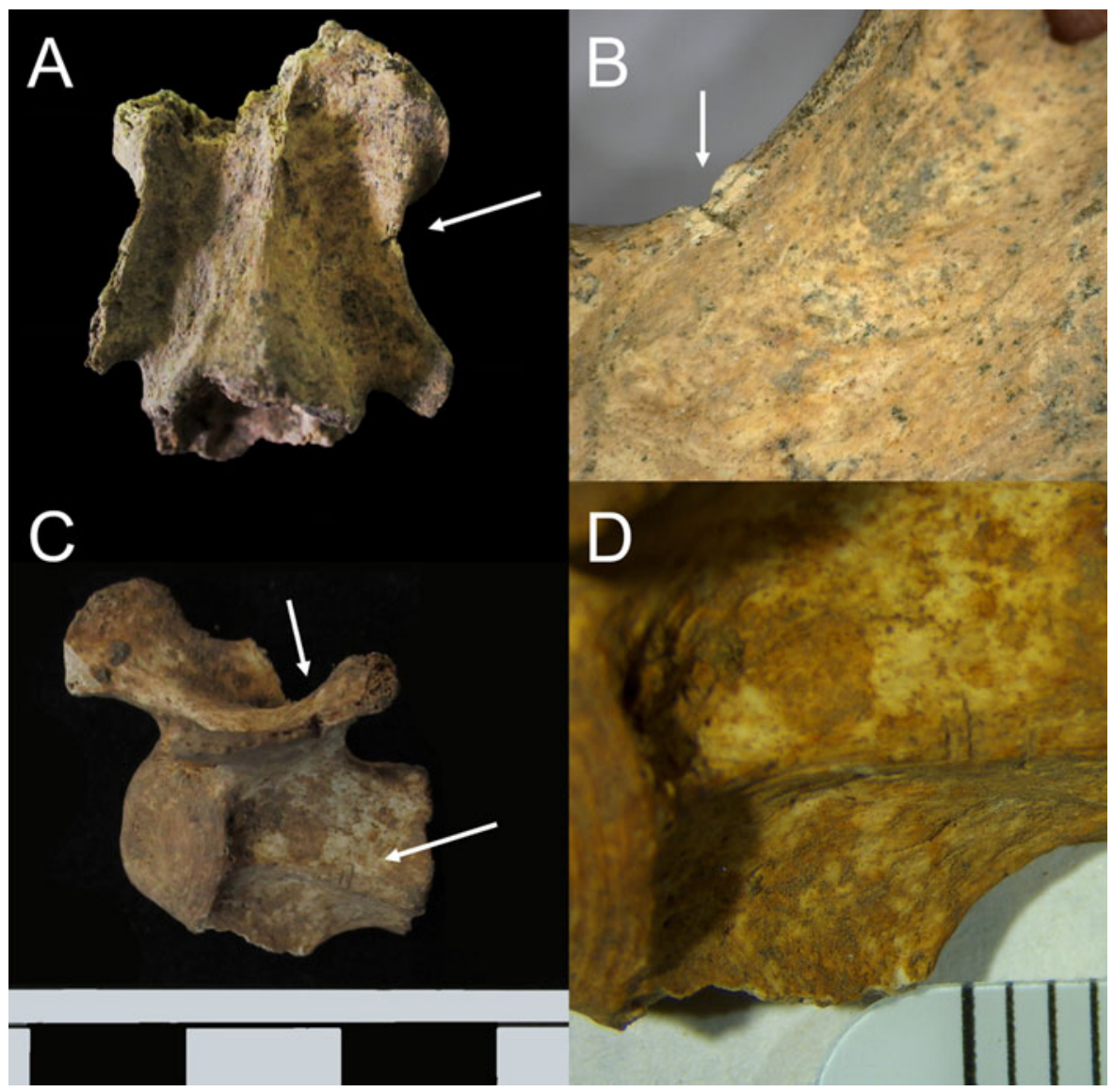

Figure 7. Cut marks on dog vertebrae: (A) and (B) cut marks under an axis vertebra from the Palangana's Gran Depósito; (C) and (D) cut marks under a cervical vertebra from a dog near Mound A-IV-1 (photographs by Ashley Sharpe). (Color online)

Developmental conditions and pathologies in dogs ranged from dental caries to more serious indicators of genetic problems (Table 3). Two-thirds of these specimens were found in the Gran Depósito. The most notable postcranial defect was a curved radius, bending outward posteriorly in the center (Figure 9A). There is no evidence that the bone had been broken during life, and there were no lesions on the exterior surface. The radius had a recent break that allowed observation of the interior, and there was no sign of excess growth. It is likely a form of severe bowleggedness, possibly caused by premature fusion of the distal epiphysis (Amy Stone, personal communication 2020).

Dental caries were uncommon, because many dogs were young and exhibited little tooth wear.
More common, however, was the reduced number of teeth possibly caused by a genetic defect. Eight specimens representing an MNI of six dogs exhibited this trait, all with varying numbers of missing teeth (Figure 9B). Often the mandibular premolars were missing, replaced by a low ridge of bone, but in one case the second and third mandibular molars were missing. In another case a maxillary premolar was missing. Seven of the specimens missing teeth (five dogs) were recovered in the Gran Depósito. The eighth specimen was with the disarticulated skeleton with cut marks near Mound A-IV-1. These dogs may be ancestors of the hairless breed known as the xoloitzcuintli, a breed possessing a chromosomal mutation that frequently results in incomplete detention in both the 


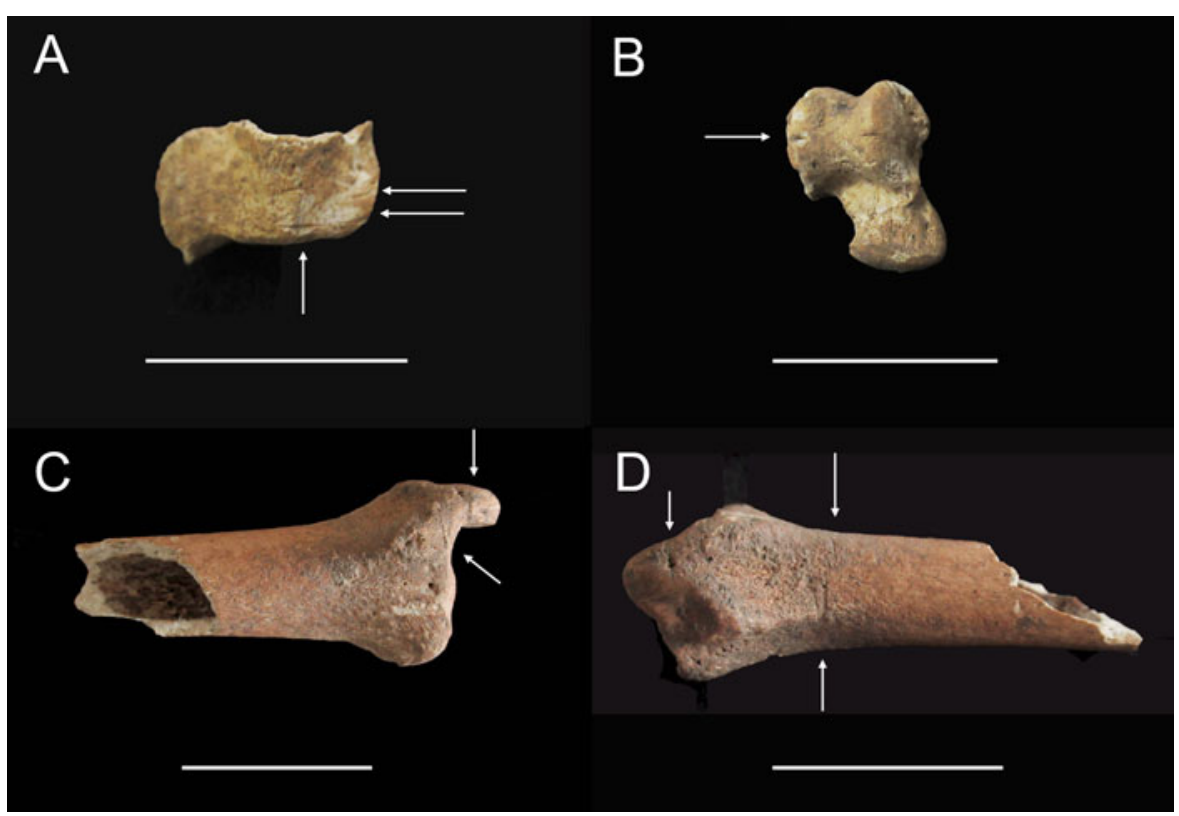

Figure 8. Light cut marks on the unfused left distal radius (A), right talus (B), and distal right tibia (C and D) of dog found near Mound A-IV-1. Scale bars $2 \mathrm{~cm}$ (photographs by Ashley Sharpe). (Color online)

Table 3. Pathologies and Developmental Conditions in the Kaminaljuyu Dogs.

\begin{tabular}{lllc}
\hline Location & Period & Condition & No. of Specimens \\
\hline Mound E-III-3 Base & Late Preclassic & Tooth crowding & 1 \\
Gran Depósito & Terminal Preclassic & Missing dentition & $7 *$ \\
& & Malformed tooth & 3 \\
& & Tooth crowding & 3 \\
& & Dental caries & 3 \\
A-IV-1/A-IV-2 Area & Terminal Preclassic & Abnormal bone development & 4 \\
& & Missing dentition & 1 \\
Acropolis & Mixed Classic & Malformed tooth & 2 \\
Total & & Malformed tooth & 1 \\
\hline
\end{tabular}

*Seven specimens with an MNI of five dogs.

mandible and maxilla (Kupczik et al. 2017). If so, the dogs interred in the Gran Depósito may have been specially selected for this reason.

\section{Discussion}

Recent excavations at Kaminaljuyu recovered a variety of species that provides insight into ancient Maya highland ceremonies. The most common animals in terms of ubiquity and abundance were dogs, suggesting canines played a significant role in ceremonial activities. The majority of animals came from special deposits from the Late Preclassic through Early Classic periods, when Kaminaljuyu was developing its control over the obsidian trade route and its political connections with neighboring highland and distant lowland communities. Although the Acropolis and Mounds A-IV-1/A-IV-2 had relatively small assemblages, they still provide important information about the use of animals at the site.

We discuss the results in comparison with other studies in Mesoamerica to address our 


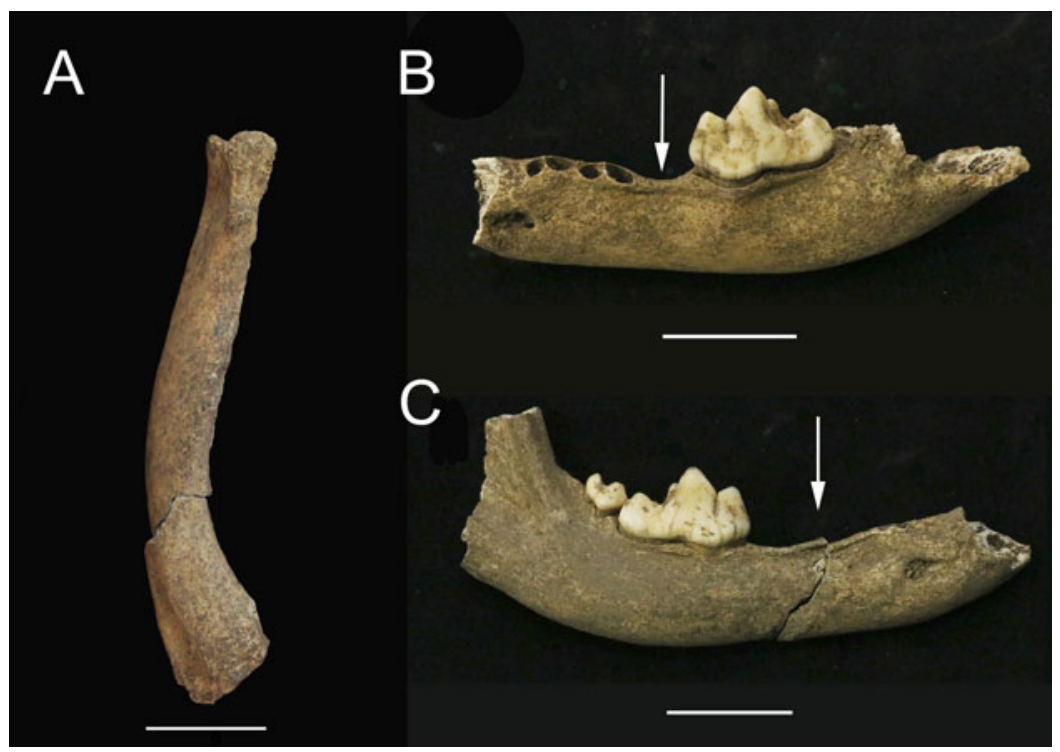

Figure 9. Dogs from the Gran Depósito: (A) radius with an unusually curved shaft; (B) left and (C) right mandibles with diastema from missing premolars marked by arrow. Scale bars $2 \mathrm{~cm}$ (photographs by Ashley Sharpe). (Color online)

original questions: Can we determine the nature and purpose of the different ceremonial deposits at Kaminaljuyu? Did Kaminaljuyu's populace engage in ceremonial activities similar to those elsewhere in Mesoamerica? Did early elites presiding over ceremonies procure rare or nonlocal animals, demonstrating their ability to obtain these resources? Finally, what was the role of dogs in ceremonies, and can Kaminaljuyu's assemblages help us understand the ritual roles of dogs in Mesoamerica?

\section{Interpreting Kaminaljuyu's Animal Ceremonies}

The deposits in this analysis fall under three broad categories: animal offerings and feasting remains associated with human burials (Mound E-III-3's base deposit, the Mound A-IV-1/ A-IV-2 burials, and possibly the Gran Depósito); animals as offerings in ceremonial events that took place over a period of time (the Gran Depósito); and animals in deposits and fill that may be primary midden discard (Mound A-IV-1/ A-IV-2's nonburial deposits) or secondary midden debris (the Acropolis).

There is considerable variability among the burial deposits. The Mound A-IV-1/A-IV-2 area burials were likely non-elite individuals, with a small number of items bearing personal or mortuary significance. The partial antlers found with two burials reflect a widespread Maya funerary practice spanning the Late Preclassic through Classic period. Remains of worked and unworked antlers have been found in human burials from Caracol (Teeter 2004) and Cahal Pech (Awe 2013) in Belize, Ceibal (Sharpe et al. 2020) in Guatemala, and Copan (Sugiyama et al. 2019) in Honduras. They may have been ornamental objects, including headdresses.

The case of the Early Classic opossum effigy vessel and complete opossum skeleton buried with an adolescent near Mound A-IV-1 has no parallels in the Maya area. The opossum may have been an emblem of the deceased person's identity or animal spirit (Holland 1964). A similar, but more grandiose, example was found in the tomb of the Maya king, Yax Nuun Ayiin I ("First Crocodile, Curl Nose") at Tikal, who was buried alongside a crocodile (Wright 2005). Another possibility could be that the opossum was a companion for this adolescent to the afterlife. Complete dog skeletons were found in three Early Classic burials in Kaminaljuyu's Mounds A and B (Kidder et al. 1946:155), interpreted as canine companions.

The deposit at the base of Mound E-III-3 had more fauna than the elite tombs uncovered in the 
same structure. The animal assemblage more closely resembled the Early Classic Mounds A and B tombs (Kidder et al. 1946:145-157). If the Mound E-III-3 deposit is an elite tomb, it may have housed one of the earliest rulers identified in the Maya area (Estrada de la Cerda 2017:23). However, because the original burials were disturbed and the artifacts were scattered and burned throughout the deposit, this context may instead be a dedication offering. Evidence of cut marks on bones indicates that at least some animals were consumed and then deposited in the offering. Combined with the hundreds of shattered vessels, including decorative wares, the deposit resembles the remains of a feast (Rosenswig 2007). This may have been a ceremony associated with the construction of Mound E-III-3, in which the remains were purposefully interred and burned. Similar dedication ceremonies involving smashed vessels, burned artifacts, and even occasionally human interments preceding the construction of a structure have been found in the Maya Lowlands (for a review, see Aimers et al. 2020).

The variety of marine fish found in the E-III-3 deposit is an indication that the Late Preclassic inhabitants of Kaminaljuyu had contact with the coasts. Although some of the identified fish species are amphidromous and can migrate between freshwater and saltwater (including snook and mullet), snappers are predominantly marine. The presence of Pacific sleepers indicates that fish were obtained from the west or south. This species prefers shallow marine and brackish water; although it tolerates freshwater, it does not swim far upstream (Galván-Quesada et al. 2016). It is uncommon archaeologically, with Ujuxte being one of the few sites where it has been identified (Wake 2000:59).

There is evidence of marine fish exchange from the Atlantic at inland Maya communities, such as Classic period Caracol (Teeter 2004) and Postclassic Mayapan (Jiménez-Cano and Masson 2016; Masson and Peraza Lope 2008). Fish at these sites included catfish, snappers, and parrotfish, the first two of which were found at Kaminaljuyu. There is also evidence of marine fish exchange for primarily ceremonial purposes in central Mexico during the Classic and Postclassic periods, including at Teotihuacan and the Templo Mayor in Tenochtitlan (López Luján et al. 2014; Rodríguez Galicia and Valadez Azúa 2013).

Our results show that Kaminaljuyu's inhabitants procured marine fish during the Late Preclassic period, centuries earlier than much of Mesoamerica. The fish may have been dried and salted for transport, as has been suggested for the Yucatan (Jiménez-Cano and Masson 2016) and as occurs today in highland markets. This may be evidence that long-distance fish transport occurred during the formation of early states near the Pacific coast, perhaps as part of the obsidian trade network. It may also be that fish acquisition was primarily conducted for ceremonial activities, like the Mound E-III-3 deposit. Emery and colleagues (2013) found a few snapper and grouper bones in the fill around the Kaminaljuyu Archaeological Park dating to the Classic period, indicating that fish transport took place for many centuries. We do not know the extent to which marine fish played a role in highland socioeconomics, but future studies may provide more information.

The Palangana's Gran Depósito represents a series of events confined to the Inferior Plaza. In addition to human interments and animals, the deposit includes thousands of complete and shattered ceramic vessels, stone tools, precious objects of mica and jade, and other remains. Some animal bones were cut, so the deposit may represent feasting remains. The large number of dogs indicates the ceremonies served a specific function, described in the next section.

The third type of deposit at Kaminaljuyu represents animal discard in primary or secondary middens. This includes the animal concentrations unassociated with human burials around Mounds A-IV-1 and A-IV-2 and the fill around the Acropolis. Species in both areas are similar and mainly include dogs and deer. Both areas also have a high proportion of bones exhibiting cut marks. Burke and colleagues (2020) describe middens as containing principally local or domestic fauna with cut marks indicative of consumption. This generally matches the description of these deposits. The presence of nonlocal turkeys at the Acropolis indicates that, by the Classic period, the royal elites who lived in this part of the site had privileged access to these birds. 


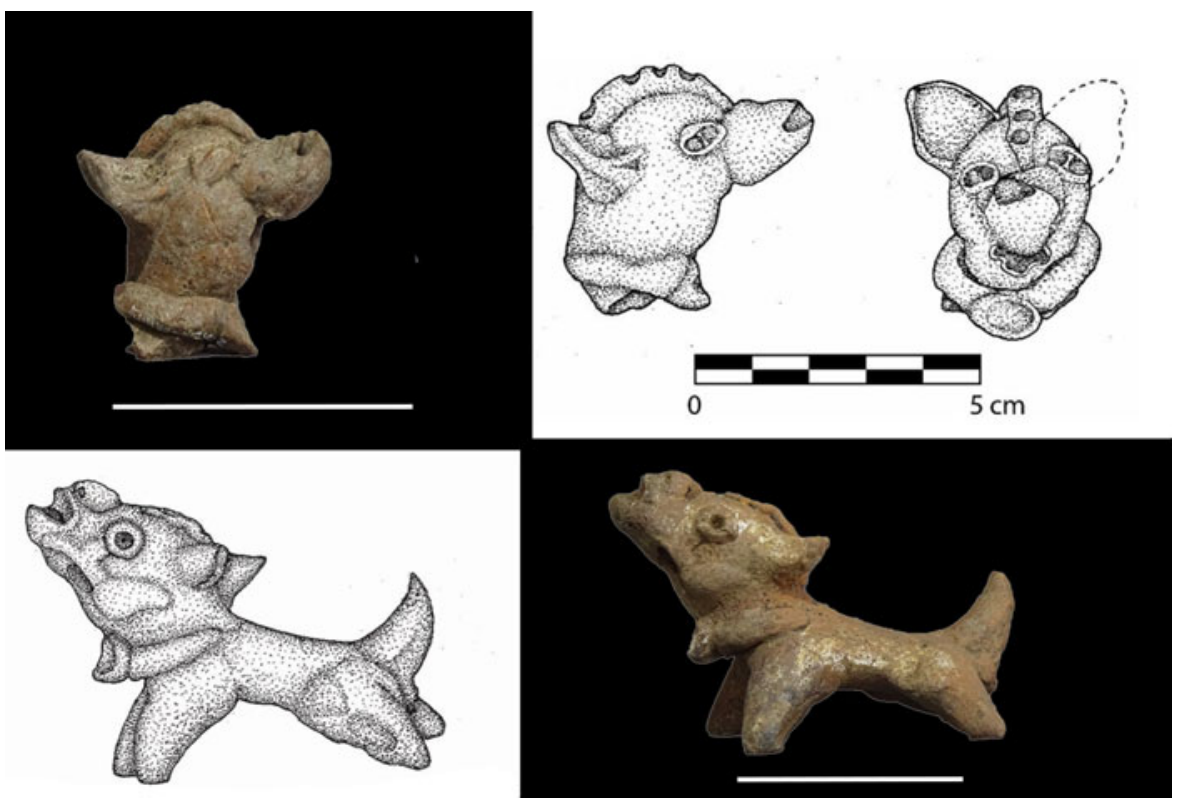

Figure 10. Dog-shaped ceramic whistles from Terminal Preclassic deposits near Mound A-IV-2. Scale bars $5 \mathrm{~cm}$ (drawings and photographs by Emanuel Serech). (Color online)

\section{The Ceremonial Role of Dogs}

Dogs clearly played an important role during Kaminaljuyu's Preclassic and Early Classic periods. The dogs in the Mound E-III-3 deposit and the Palangana's Gran Depósito may have been the disarticulated remains of feasting activity associated with these deposits. The events responsible for these deposits may have been similar to the feasting events identified at Preclassic sites in Oaxaca that involved large numbers of dogs (Pérez Rodríguez et al. 2017; Rosenswig 2007). Such events have been interpreted as displays of early elite power, similar to feasting activity in other parts of the world (deFrance 2009). However, even if some of these dogs were consumed, they may still have served a role as offerings.

The fact that several dogs in the Gran Depósito possibly belonged to the hairless breed indicates they may have been specially selected for rituals. Currently, the earliest evidence for this breed is from Classic period deposits at Guadalupe (Rodríguez Galicia et al. 2001), Tula (Valadez Azúa et al. 1999), and Tizayuca (Manin et al. 2018) in central Mexico. Other examples can be found throughout Mexico dating to the Postclassic period (AD 900-1500; Valadez Azúa 2020; Valadez Azúa et al. 2013). Very few hairless dogs have been found in the Maya area. Two possible specimens come from Late Classic deposits at Copan, Honduras (Collins 2002:156; Pohl 1994:468), and several Postclassic specimens were recovered from Champotón in Campeche (Götz 2015:110) and nearby Chac Mool (Blanco Padilla et al. 2008). The new Kaminaljuyu evidence suggests the hairless breed existed in southern Guatemala during the Terminal Preclassic period and calls into question where, how, and why the breed spread throughout Mesoamerica.

The hairless breed likely originated in central Mexico based on zooarchaeological and genetic data (Blanco Padilla et al. 2008; Manin et al. 2018). Certain characteristics of the dog are depicted in Mexican precolumbian art, including its prominent wrinkles and large ears, although these images could also represent short-haired dogs (Valadez Azúa 1996, 2020). Excavations around Mounds A-IV-1/A-IV-2 recovered dogshaped figurines and whistles, including some with a hair tuft between the ears that xoloitzcuintli have (Figure 10; for a complete list, see Serech 2018). Because lack of teeth alone is not a definitive marker for hairlessness, genetic analysis of the dogs is planned. If confirmed, these may be the earliest known Mesoamerican hairless dogs. 
Dogs may have been the preferred sacrificial animal for certain special events at Kaminaljuyu. Since dog ages varied in the Gran Depósito, they did not come from the same litter. The fact that one adult dog had a severely curved radius that would have impeded its ability to walk suggests that this dog had been cared for to some extent. The dogs may have been contributions from individuals living in or near Kaminaljuyu, or they may have come from farther away, including central Mexico. Archaeological remains identified as hairless dogs from other Mesoamerican sites are often, but not always, found as sacrificial offerings and in human burials (for a review, see Valadez Azúa 2020).

The Gran Depósito may have been associated with water-related ceremonies, since the Palangana was located on the lake shore during the Terminal Preclassic period. An historic example of hairless dog sacrifice for an aquatic ritual can be found in Diego Muñoz Camargo's Historia de Tlaxcala (ca. 1592), in which he describes a ceremony dedicated to requesting rain during periods of drought. A group of hairless dogs were brought to the Tlaxcalan temple, Xoloteupen, for sacrifice (Muñoz Camargo 1892 [1592]: 155-156). The dogs' hearts were removed and offered to the water deities, and afterward the dogs themselves were consumed. Such an event may leave behind disarticulated and burned remains, like those found in the Palangana.

The fact that the concentration of dog deposits occurred in the Inferior Plaza on the Palangana's western side indicates that it may be associated with the underworld. Mesoamerican cosmology associates the western direction with the sun's passage into the watery underworld, and directional symbolism often associates the west with death (Milbrath 1999:21). In Mesoamerican myths, dogs were believed to know the way to the underworld and could serve as guides for humans (Sahagún 1938:285-286). This may have been the purpose of the complete dog skeletons interred in the royal burials of Mounds A and B (Kidder et al. 1946:155), a practice that is primarily found in central Mexican sites (Valadez Azúa et al. 2013). Dogs have also been found in cave deposits in central Mexico, interpreted as offerings to the supernatural underworld (Monterroso Rivas 2004; Valadez Azúa and Rodríguez 2010).
Although dogs are described as sacrificial offerings in early Spanish historical accounts (Landa 1941:164; Sahagún 1938:186, 316) and the Maya Popol Vuh myth (Tedlock 1996:134135), clear evidence of dog sacrifice in the Maya archaeological record is difficult to identify. A concentration of Terminal Classic dog remains found at Lagartero was interpreted as discard from a feasting event (Koželsky 2005). Several puppies were found in a Late Classic period reservoir near the royal palace at Cancuen, along with several humans (who may have been massacred members of the royal court; Thornton and Demarest 2019). Zaculeu, located near Kaminaljuyu in the Guatemalan highlands, contained adult and puppy skeletons in human graves (Woodbury and Trik 1953:392). Each of these cases is unique to the individual circumstances of the site, although the finds at Zaculeu resemble the dog burials at Kaminaljuyu and central Mexico.

Although we know that Kaminaljuyu had a close political relationship with Teotihuacan in the Early Classic period, the presence of possible hairless dogs in a ceremonial deposit from the Preclassic indicates that a relationship had existed between Kaminaljuyu and central Mexico centuries earlier. If true, this connection included not only the shared symbolic use of dogs but also the movement of hairless dogs into the Maya area. Our understanding of the Preclassic relationship between the Maya and central Mexican cultural regions is still vague. The presence of hairless dogs in Maya Preclassic highland ceremonies indicates that the connection may have been stronger than is currently known.

\section{Conclusions}

The faunal remains recovered during recent excavations at Kaminajuyu provide important information about highland rituals during the Late Preclassic and Early Classic periods, a time when royal elites emerged in the Maya region. Although the purpose of some ceremonial contexts, particularly the Gran Depósito, remains ambiguous, we were able to distinguish uses of fauna in burial and nonburial deposits. The Preclassic burials and dedication deposit below 
Mound E-III-3 were filled with diverse offerings: dogs, deer, birds, and freshwater and marine fish. We can surmise that Kaminaljuyu's inhabitants had developed a method for procuring fish from the Pacific coast by the Late Preclassic period. Currently, this is one of the earliest reports of marine fish at an inland site in Mesoamerica.

Dogs were particularly significant in Kaminaljuyu's Late Preclassic and Early Classic society. They were included in the possible feast remains burned in the Mound E-III-3 base deposit, but they were also found as complete skeletons in the Mound A and B tombs. The Gran Depósito appears to be an important series of events involving the interment of numerous dogs. If these are hairless dogs, this find indicates that they reached Kaminaljuyu by the Preclassic period. Hairless dogs may have been specifically chosen as offerings due to their association with the underworld.

Despite Kaminaljuyu being the largest ancient highland Maya center, most of what we know about its relationship with animals comes from ceremonial deposits and art, rather than domestic and utilitarian contexts. This bias is the product of two principal factors: first, the bones of special contexts were often buried quickly, so as to not leave them exposed to scavengers and weathering; second, most excavations have occurred around large mounds where the chances of finding funerary and offering deposits are high. Unfortunately, with most of the ancient settlement now underneath or destroyed by the modern city, we may never learn the full story of what happened at Kaminaljuyu. This includes how severe an impact the loss of Lake Miraflores had on subsistence activities, how widely marine fish were available to the community, how common were hairless dogs, and what Kaminaljuyu's Preclassic relationship had been like with central Mexico. Yet despite its deteriorated state, Kaminaljuyu still has much to offer, and every new excavation provides more pieces to reconstruct the puzzle of its enigmatic past.

Acknowledgments. The authors are grateful for the assistance of the ZAK excavation team. We thank Amy Stone and Petra Cunningham-Smith for their advice on the canine pathologies, Thomas Wake and Máximo Jiménez for their assistance identifying the fish specimens, Kitty Emery for offering information regarding faunal analysis from previous excavations, and the reviewers' recommendations. Permits included D.A.J.-446-2017 from the Instituto de Antropología e Historia in Guatemala, and Resolución $N^{\circ}$ 117-17 from the Instituto Nacional de Cultura in Panamá. This research was funded by the Alphawood Foundation and Smithsonian Tropical Research Institute.

Data Availability Statement. Original data are available in this manuscript and supplementary files. Excavated materials are stored at the ZAK project laboratory (Zona 7, Guatemala City) and Instituto de Antropología e Historia de Guatemala storage facilities (Zona 1, Guatemala City; vu.demopre@ gmail.com).

Supplemental Material. For supplemental material accompanying this article, visit https://doi.org/10.1017/laq.2021.81.

Supplemental Table 1. Specimens with Modifications from Butchery Activities and Artifact Manufacture.

Supplemental Table 2. Expanded Summary of Specimen Identifications.

Supplemental Table 3. Identifications by Context Type in the Mound A-IV-1/A-IV-2 Area.

Supplemental Table 4. Fusion of Dog Elements.

\section{References Cited}

Aimers, James J., Julie A. Hoggarth, and Jaime J. Awe 2020 Decoding the Archaeological Significance of Problematic Deposits in the Maya Lowlands. Ancient Mesoamerica 31:67-75.

Ajú Álvarez, Gloria

2014 Excavaciones en la Palangana. In Informe Final Zona Arqueológica Kaminaljuyu Temporada 2014, edited by Bárbara Arroyo, pp. 6-93. Instituto de Antropología e Historia, Guatemala City.

2017 La Palangana, Kaminaljuyu: Su integración a la geografía sagrada en el Preclásico y Clásico. Licenciatura thesis, Escuela de Historia, Universidad de San Carlos, Guatemala City.

Aoyama, Kazuo

2017 Preclassic and Classic Maya Interregional and LongDistance Exchange: A Diachronic Analysis of Obsidian Artifacts from Ceibal, Guatemala. Latin American Antiquity 28:213-231.

Arroyo, Bárbara, and Gloria Ajú

2021 Long Distance Exchange and the Ballgame at Kaminaljuyu. In Routes, Interaction, and Exchange in the Southern Maya Region, edited by Eugenia Robinson and Gavin Davis. Routledge, London, in press.

Arroyo, Bárbara, and Lucia Henderson

2020 The Monumental Aquascape of Kaminaljuyu: Water in the Archaeology of an Early Highland Site. In Approaches to Monumental Landscapes of the Ancient Maya, edited by Brett Houk, Bárbara Arroyo, and Terry Powis, pp. 131-151. University Press of Florida, Gainesville.

Arroyo, Bárbara, Takeshi Inomata, Gloria Beatriz Ajú Álvarez, Javier Estrada, Hiroo Nasu, and Kazuo Aoyama

2020 Refining Kaminaljuyu Chronology: New Radiocarbon Dates, Bayesian Analysis, and Ceramics Studies. Latin American Antiquity 31:477-497.

Awe, Jaime J.

2013 Journey on the Cahal Pech Time Machine: An 
Archaeological Reconstruction of the Dynastic Sequence at a Belize Valley Maya Polity. Research Reports in Belizean Archaeology 10:33-50.

Blanco Padilla, Alicia, Christopher Götz, Gabriel Mestre, Bernardo Rodríguez Galicia, and Raúl Valadez Azúa

2008 El xoloitzcuintle prehispánico y el estándar actual de la raza. AMMVEPE 19(5):131-138.

Braswell, Geoffrey E.

2003 Understanding Early Classic Interaction between Kaminaljuyu and Central Mexico. In The Maya and Teotihuacan: Reinterpreting Early Classic Interaction, edited by Geoffrey E. Braswell, pp. 105-142. University of Texas Press, Austin.

Burke, Chrissina, Katie Tappan, Gavin Wisner, Julie Hoggarth, and Jaime Awe

2020 To Eat, Discard, or Venerate: Faunal Remains as Proxy for Human Behaviors in Lowland Maya PeriAbandonment Deposits. Ancient Mesoamerica 31:127-137.

Collins, Lisa M.

2002 The Zooarchaeology of the Copan Valley: Social Status and the Search for a Maya Slave Class. PhD dissertation, Department of Anthropology, Harvard University, Cambridge, Massachusetts.

deFrance, Susan D.

2009 Zooarchaeology in Complex Societies: Political Economy, Status, and Ideology. Journal of Archaeological Research 17:105-168.

Emery, Kitty, Erin Kennedy Thornton, Nicole Cannarozzi, Stephen Houston, and Héctor Escobedo

2013 Ancient Animals of the Southern Maya Highlands: Zooarchaeology of Kaminaljuyu. In The Archaeology of Mesoamerican Animals, edited by Christopher Götz and Kitty Emery, pp. 381-416. Lockwood Press, Atlanta, Georgia.

Estrada de la Cerda, Javier

2017 Caminos ancestrales: Las rutas de Kaminaljuyu durante el Preclásico Tardío. Licenciatura thesis, Escuela de Historia, Universidad de San Carlos, Guatemala City.

Galván-Quesada, Sesángari, Ignacio Doadrio, Fernando Alda, Anabel Perdices, Ruth Gisela Reina, Martín Varela, Natividad Hernández, Antonio Mendoza, Eldredge Bermingham, and Omar Domínguez-Domínguez

2016 Molecular Phylogeny and Biogeography of the Amphidromous Fish Genus Dormitator. PLoS ONE 11 (4): 0153538.

Götz, Christopher

2015 Uso, consumo y crianza de animales vertebrados en el período posclásico de Champotón. In Pasos largos al futuro: La resiliencia socio-ecológica de los Mayas de Campeche en relación a los cambios climáticos, edited by Betty Faust and William Folan, pp. 107-124. Universidad Autónoma de Campeche, Campeche, Mexico.

Henderson, Lucia Ross

2013 Bodies Politic, Bodies in Stone: Imagery of the Human and the Divine in the Sculpture of Late Preclassic Kaminaljuyú, Guatemala. PhD dissertation, Department of Art and Art History, University of Texas, Austin.

Holland, William

1964 Contemporary Tzotzil Cosmological Concepts as a Basis for Interpreting Prehistoric Maya Civilization. American Antiquity 29:301-306.

Ivic de Monterroso, Matilde, and Carlos Alvarado Galindo

2004 Kaminaljuyu: Informe de las excavaciones realizadas en el Parque Kaminaljuyu, Guatemala. Report presented to the Instituto de Antropología e Historia, Guatemala City.

Jiménez-Cano, Nayeli G., and Marilyn A. Masson

2016 Estimation of Fish Size from Archaeological Bones of Hardhead Catfishes (Ariopsis felis): Assessing Pre-Hispanic Fish Acquisition of Two Mayan Sites. Journal of Archaeological Science: Reports 8:116-120.

Kidder, Alfred V., Jesse D. Jennings, and Edwin M. Shook

1946 Excavations at Kaminaljuyu, Guatemala, Publication 561. Carnegie Institution of Washington, Washington, DC.

Koželsky, Kristin L.

2005 Identifying Social Drama in the Maya Region: Fauna from the Lagartero Basurero, Chiapas, Mexico. Master's thesis, Department of Anthropology, Florida State University, Tallahassee.

Kupczik, Kornelius, Alexander Cagan, Silke Brauer, and Martin Fischer

2017 The Dental Phenotype of Hairless Dogs with FOXI3 Haploinsufficiency. Scientific Reports 7:5459.

Landa, Diego de

1941 Landa's Relación de las Cosas de Yucatán. Translated by Alfred Tozzer. Papers of the Peabody Museum of Archaeology and Ethnology 18. Harvard University, Cambridge, Massachusetts.

López Luján, Leonardo, Ximena Chávez Balderas, Belem Zúñiga-Arellano, Alejandra Aguirre Molina, and Norma Valentín Maldonado

2014 Entering the Underworld: Animal Offerings at the Foot of the Great Temple of Tenochtitlan. In Animals and Inequality in the Ancient World, edited by Benjamin Arbuckle and Sue Ann McCarty, pp. 33-62. University Press of Colorado, Boulder.

Love, Michael W.

2011 City States and City-State Culture in the Southern Maya Region. In The Southern Maya in the Late Preclassic: The Rise and Fall of an Early Mesoamerican Civilization, edited by Michael W. Love and Jonathan Kaplan, pp. 47-76. University Press of Colorado, Boulder.

Manin, Aurélie, Morgane Ollivier, Fabiola Bastian, Antoine Zazzo, Olivier Tombret, Juan Carlos Equihua Manrique, and Christine Lefèvre

2018 Can We Identify the Mexican Hairless Dog in the Archaeological Record? Morphological and Genetic Insights from Tizayuca, Basin of Mexico. Journal of Archaeological Science 98:128-136.

Masson, Marilyn A., and Carlos Peraza Lope

2008 Animal Use at the Postclassic Maya Center of Mayapán. Quaternary International 191:170-183.

Milbrath, Susan

1999 Star Gods of the Maya: Astronomy in Art, Folklore, and Calendars. University of Texas Press, Austin.

Monterroso Rivas, Pablo Neptali

2004 Los entierros de la cueva del Tecolote, análisis antropológico de un ritual. Licenciatura thesis, Escuela Nacional de Antropología e Historia, Mexico City.

Muñoz Camargo, Diego

1892 [1592] Historia de Tlaxcala. Edited by Alfredo Chavero. Oficina Tip. de la Secretaria de Fomento, Mexico City.

Murphy, Eileen

2001 Medieval and Post-Medieval Butchered Dogs from Carrickfergus, Co. Antrim, Northern Ireland. Environmental Archaeology 6:13-22. 
Pérez Rodríguez, Verónica, Antonio Martínez Tuñón, Laura Stiver Walsh, Gilberto Pérez Roldán, and Fabiola Torres Estévez

2017 Feasting and Building an Urban Society at Cerro Jazmín, Oaxaca, Mexico. Journal of Field Archaeology 42:115-128.

Pohl, Mary D.

1994 Late Classic Maya Fauna from Settlements in the Copán Valley, Honduras. In Ceramics and Artifacts from Excavations in the Copán Residential Zone, edited by Gordon R. Willey, Richard M. Leventhal, Arthur A. Demarest, and William L. Fash, pp. 459-476. Papers of the Peabody Museum of Archaelogy and Ethnology 80. Harvard University, Cambridge, Massachusetts.

Popenoe de Hatch, Marion, Erick Ponciano, Tomás Barriento, Mark Brenner, and Charles Ortloff

2002 Climate and Technological Innovation at Kaminaljuyú, Guatemala. Ancient Mesoamerica 13:103-114.

Reitz, Elizabeth J., and Elizabeth S. Wing

2008 Zooarchaeology. 2nd ed. Cambridge Manuals in Archaeology. Cambridge University Press, Cambridge.

Rodriguez Galicia, Bernardo, and Raúl Valadez Azúa

2013 Coastal Resources in the City of the Gods. In The Archaeology of Mesoamerican Animals, edited by Christopher Götz and Kitty Emery, pp. 49-80. Lockwood Press, Atlanta.

Rodríguez Galicia, Bernardo, Raúl Valadez Azúa, Gregory Pereira, Fernando Viniegra Rodriguez, Katiuska Olmos Jiménez, and Alicia Blanco Padilla

2001 Restos arqueozoologicos de perros (Canis familiaris) encontrados en el sitio de Guadalupe, Estado de Michoacan. AMMVEPE 12(6):199-209.

Rosenswig, Robert M.

2007 Beyond Identifying Elites: Feasting as a Means to Understand Early Middle Formative Society on the Pacific Coast of Mexico. Journal of Anthropological Archaeology 26:1-27.

Sahagún, Bernardino de.

1938 Historia General de las Cosas de Nueva España. Editorial Pedro Robredo, Mexico City.

Serech, Emanuel

2017 La ecología y la fauna en Kaminaljuyu. Editorial Galería Guatemala 56:72-77.

2018 El entorno natural y las relaciones ecológicas de Kaminaljuyu del Preclásico Tardío al Clásico Temprano, visto desde las manifestaciones de fauna entre los Montículos A-IV-1 y A-IV-2. Licenciatura thesis, Escuela de Historia, Universidad de San Carlos, Guatemala City.

Sharpe, Ashley, Takeshi Inomata, Daniela Triadan, Melissa Burham, Jessica MacLellan, Jessica Munson, and Flory Pinzón

2020 The Maya Preclassic to Classic Transition Observed through Faunal Trends from Ceibal, Guatemala. PLOS ONE 15(4):e0230892.

Shook, Edwin M., and Alfred V. Kidder

1952 Mound E-III-3, Kaminaljuyu, Guatemala. Contributions to American Anthropology and History 53. Publication 596. Carnegie Institution of Washington, Washington, DC.

Sugiyama, Nawa, William Fash, and Christine A. M. France

2019 Creating the Cosmos, Reifying Power: A Zooarchaeological Investigation of Corporal Animal Forms in the Copan Valley. Cambridge Archaeological Journal 29:407-426.
Sugiyama, Nawa, Andrew D. Somerville, and Margaret Schoeninger

2015 Stable Isotopes and Zooarchaeology at Teotihuacan, Mexico Reveal Earliest Evidence of Wild Carnivore Management in Mesoamerica. PLoS ONE 10(9): e0135635.

Tedlock, Dennis

1996 Popol Vuh: The Mayan Book of the Dawn of Life. Rev. ed. Touchstone, New York.

Teeter, Wendy G.

2004 Animal Utilization in a Growing City: Vertebrate Exploitation at Caracol, Belize. In Maya Zooarchaeology: New Directions in Method and Theory, edited by Kitty F. Emery, pp. 177-192. UCLA Cotsen Institute of Archaeology, Los Angeles.

Thornton, Erin Kennedy, and Arthur A. Demarest

2019 At Water's Edge: Ritual Maya Animal Use in Aquatic Contexts at Cancuen, Guatemala. Ancient Mesoamerica 30:473-491.

Thornton, Erin Kennedy, and Kitty Emery

2017 The Uncertain Origins of Mesoamerican Turkey Domestication. Journal of Archaeological Method and Theory 24:328-351.

Valadez Azúa, Raúl

1996 Estudio del perro mesoamericano. AMMVEPE 7(3):111-117.

2020 Colección arqueozoológica de perros pelones mexicanos del Instituto de Investigaciones Antropológicas de la Universidad Nacional Autónoma de México. Paleoindian Archaeology 2(1):19-42.

Valadez Azúa, Raúl, Alicia Blanco Padilla, Bernardo Rodríguez Galicia, and Gilberto Pérez Roldán

2013 The Dog in the Mexican Archaeozoological Record. In The Archaeology of Mesoamerican Animals, edited by Christopher Götz and Kitty Emery, pp. 557-582. Lockwood Press, Atlanta, Georgia.

Valadez Azúa, Raul, Blanca Paredes Gudino, and Bernardo Rodríguez Galicia

1999 Entierros de perros descubiertos en la antigua ciudad de Tula. Latin American Antiquity 10:180-200.

Valadez Azúa, Raúl, and Bernardo Rodríguez

2010 Una historia de perros al pie de la Pirámide del Sol. AMMVEPE 21(5):109-124.

Von Pfeil, Dirsko J., and Charles E. DeCamp

2009 The Epiphyseal Plate: Physiology, Anatomy, and Trauma. Compendium: Continuing Education for Veterinarians 31(8):E1-11.

Wake, Thomas A.

2000 Analisis preliminar de la fauna de Ujuxte. In Trabajos de analisis del Proyecto Ujuxte: Informe Preliminar Entregado al Instituto de Arqueologia e Historia de Guatemala, edited by Michael Love and Donald Castillo V., pp. 57-62. Instituto de Antropología e Historia, Guatemala City.

Woodbury, Richard Benjamin, and Aubrey S. Trik

1953 The Ruins of Zaculeu, Guatemala. United Fruit Company, William Byrd Press, New York.

Wright, Lori

2005 In Search of Yax Nuun Ayiin I: Revisiting the Tikal Project's Burial 10. Ancient Mesoamerica 16:89-100.

Submitted February 16, 2021; Revised August 10, 2021; Accepted August 17, 2021 